\title{
The First Year of Bolsonaro in Office: Same Old Story, SAME Old Song?*
}

\author{
El primer año de gobierno de Bolsonaro. ¿La misma vieja historia, la \\ misma vieja canción?
}

\section{OCTAVIO AMORIM NETO}

Getulio Vargas Foundation (FGV), Rio de Janeiro, Brasil

\section{GABRIEL ALVES PIMENTA}

University of California, Riverside, USA

\begin{abstract}
The rise of Bolsonaro is the latest episode of what seems to be a Brazilian tradition of electing rightwing populists as a response to corruption, bad economic management, and disenchantment with mainstream political parties. In previous opportunities, Brazilians elected Jânio Quadros (1960) and Fernando Collor (1989). However, Bolsonaro, although very similar to both Quadros and Collor on their hostility to parties and legislative institutions, brought novel elements. To identify the distinguishing features of Brazil's new president, we systematically compare Quadros, Collor, and Bolsonaro along 13 dimensions encompassing political context and attributes, policy choices, and institutional relations. Our findings indicate that throughout 2019, Bolsonaro led an unstable minority administration that governed for a minority in society and emphatically excluded some relevant sectors. Moreover, he established close connections with Evangelical groups and the military, and attacked the press and the Supreme Court at an unprecedented level.
\end{abstract}

Keywords: Jânio Quadros, Fernando Collor, Latin American populism, rightwing presidents, minority government

\begin{abstract}
RESUMEN
El ascenso de Bolsonaro es el último episodio de la que parece ser una tradición brasileña: elegir populistas de derecha como respuesta a la corrupción, la mala gestión económica y al desencanto con los principales partidos políticos. En oportunidades anteriores, los brasileños eligieron a Jânio Quadros (1960) y Fernando Collor (1989). Sin embargo, Bolsonaro, si bien muy similar tanto a Quadros como a Collor en su hostilidad hacia los partidos y las instituciones legislativas, aportó elementos novedosos. Para identificar las características distintivas del nuevo presidente del Brasil, comparamos sistemáticamente a Quadros, Collor y Bolsonaro a lo largo de 13 dimensiones que abarcan el contexto y los atributos políticos, la orientación de las políticas gubernamentales y las relaciones institucionales. Nuestros hallazgos indican que durante todo el año 2019, Bolsonaro lideró una administración minoritaria e inestable que gobernó para una minoría de la sociedad y que excluyó enfáticamente algunos sectores relevantes. Además, estableció estrechas conexiones con los grupos evangélicos y los militares, y atacó a la prensa y al Tribunal Supremo a un nivel sin precedentes.
\end{abstract}

Palabras clave: Jânio Quadros, Fernando Collor, populismo latinoamericano, presidentes de derecha, gobierno minoritario

The authors thank three anonymous reviewers, Manuel Alcántara, Fernando Guarnieri, Jair Koiller, Christian Lynch, Fabiano Santos, and Eduardo Viola for comments and suggestions, and the research assistance provided by Camila Farias and Natália Lucciola. 


\section{INTRODUCTION}

On January 1, 2019, Jair Bolsonaro took office as President of Brazil, after the eighth presidential election since the country redemocratized in 1985. It is the consensus among the analysts that Bolsonaro is a far-right populist. Specialists aptly define him as a far-right politician, mostly due to his open defense of human rights' violators ${ }^{1}$ and authoritarian regimes in Latin America. However, the nature of Bolsonaro's populism needs clarification as his brand of populism is not the same as that of Donald Trump, whom Bolsonaro constantly emulates. To do so, we rely on the work of Weyland (2001).

Weyland advocates a political definition of populism in Latin America, eliminating the confusion caused by the presence of attributes of another nature, such as economic policy. In his words,

“Under populism, an individual leader seeks or exercises government power based on support from large numbers of followers. Thus, elections, referenda, mass demonstrations, and most recent opinion polls are the crucial instruments with which populist leaders mobilize and demonstrate their distinctive power capability. Populist aspirants whip up support from largely unorganized masses to win office. Populist chief executives constantly invoke their broad mass support to boost their influence and overpower their opponents' institutional bastions (Weyland 2001: 12)."

The core of Weyland's definition lies in the absence of institutional or party intermediation between the populist leader and the masses, whether he or she implements a right- or left-leaning economic policy or whether he or she has a popular social origin or not. In this sense, Luis Inácio Lula da Silva, Brazil's President in 2003-2011, is not a populist because he came to power and exercised it through the Workers' Party (PT). Lula certainly used some populist tactics and rhetoric, but he did not have populism as his primary strategy. Hugo Chávez, on the other hand, was a quintessential populist leader, since his party affiliation, the MVR (Movimiento Quinta República) and PSUV (Partido Socialista Unido de Venezuela), was never the key instrument through which he obtained and exercised power. The Chavista instrument par excellence was the permanent mobilization of radically polarizing cleavages of the friend-foe type (poor versus wealthy, rancid elites versus excluded masses, democrats versus coup mongers, and imperialists versus anti-imperialists), as Weyland emphasizes. Although Donald Trump has also been mobilizing polarizing cleavages, the Republican Party is central to his obtaining and wielding of presidential power.

Weyland's political definition of Latin American populism and Chávez's example, therefore, dovetail well with Jair Bolsonaro. Before being sworn in Presi-

Such as Colonel Carlos Alberto Brilhante Ulstra, complimented by Bolsonaro at the floor of Brazil's Lower Chamber when he voted for the impeachment of Dilma Rousseff on April 17, 2016 (Oyama 2020: 11-13). 
dent, Bolsonaro joined eight parties: the Christian Democratic Party (PDC), the Progressive Party (PP) (Bolsonaro was affiliated with the PP in two different opportunities, a brief one in 1993 and a longer one in 2005-2016), the Reform Progressive Party (PPR), the Brazilian Progressive Party (PPB), the Brazilian Labor Party (PTB), the Liberal Front Party (PFL), the Social Christian Party (PSC), and the Social Liberal Party (PSL). In March 2018 - seven months before the presidential poll -, he joined the PSL on whose ticket he was elected President. In October 2019, he bolted the PSL and, since then, has not joined any other label. The PSL played a minor role in Bolsonaro's presidential campaign, and cabinet formation, executive-legislative relations, the administration of the federal government, and the mobilization of popular support.

Weyland's definition of populism can also be aptly applied to Jânio Quadros and Fernando Collor, presidents of Brazil in 1961, and 1990-1992, respectively. Thus, Bolsonaro is Brazil's third elected rightwing populist President. Interestingly enough, precisely twenty-nine years separate the election of each successive rightwing populist (1960, 1989 and 2018). Moreover, the three of them succeeded chief executives who had led democratic coalitional presidencies associated with corruption scandals and economic crisis. Despite their populism, Quadros, Collor, and Bolsonaro had been political insiders before rising to the presidency. Quadros had been governor of São Paulo in 1955-1959, Collor had been governor of Alagoas in 1987-1989, and Bolsonaro had served as a federal deputy for no less than seven successive terms, spanning 28 years. Are the factors that contributed to the rise of these three rightwing presidencies mostly the same? What are their key similarities and differences? What are the unique features of the Bolsonaro presidency in his first year in office?

To answer those questions, the paper will proceed as follows. The second section will provide a brief account of the main facts, events, processes, and trends of the Bolsonaro presidency in 2019. Then we move on to compare Quadros, Collor, and Bolsonaro along 13 dimensions. The fourth section will identify the common core features of the three presidents and the distinguishing features of Bolsonaro in his first year in office. The fifth section will enunciate the conclusions and pin down the main political consequences of Bolsonaro's unique attributes.

\section{A BRIEF ACCOUNT OF BOLSONARO'S FIRST YEAR IN OFFICE}

Since his inauguration, the Bolsonaro government has been presenting unique features as compared to his predecessors since 1985. From the paranoid demeanor of the President to a heavily militarized cabinet and sub-cabinet appointments, the former Army captain behaved like no other president in the recent history of the country (Oyama 2020: 26-45; 71-87).

As regards cabinet appointments, as promised during the campaign, Bolsonaro has not followed the rules of Brazil's coalitional presidentialism. His first cabi- 
net had eight active-duty or military reserve officers ${ }^{2}$, nine non-partisan ministers, and only five politicians affiliated with four parties (PSL, DEM, MDB, and NOVO). Their respective parties had not officially endorsed the appointment of the "political" ministers. Indeed, this cabinet makeup is very different from those of presidents Cardoso (1995-2003), Lula (2003-2011), Rousseff (2011-2016), and Temer (2016-2019). Not surprisingly, the Bolsonaro presidency has never commanded a stable majority in Congress. Using data on roll rates, Almeida (2020) shows that the PSL, Bolsonaro's party until October 2019, was frequently defeated on the floor of the Lower House. Almeida (2020) also presents data showing that in 1989-2019 Bolsonaro's first year in office stands out for the lowest rate of executive-initiated laws per month. As important examples of Bolsonaro's legislative defeats, Congress turned down two gun-carrying relaxation acts, a decree on the limits on the transparency law, reviewed vetoes on the authority abuse act, and prevented traffic law reforms. However, the executive was able to obtain an important congressional victory with the enactment of the pension system reform on October 22, 2019. However, this victory was not an achievement of Bolsonaro because he had invested little political capital in it (Folha de São Paulo 2019).

The Bolsonaro government in 2019 can be characterized as a collection of groups that never maintained stable relations with each other. The groups are as follows: (1) the President's three sons (senator Flávio Bolsonaro, federal deputy Eduardo Bolsonaro and Rio de Janeiro city council member Carlos Bolsonaro); (2) the military; (3) the liberals (in the European sense of the word) led by minister of economy Paulo Guedes; (4) the law-and-order group led by then minister of Justice Sergio Moro; (5) the ideological representatives of Bolsonarismo (minister of family, human rights and women Damares Alves, minister of education Abraham Weintraub, minister of foreign affairs Ernesto Araújo, and minister of the environment Ricardo Salles [affiliated with NOVO till May 7, 2020]); (6) the light-weight politicians heading the staff of the presidency Onyx Lorenzoni, (DEM), the agriculture portfolio (Tereza Cristina, DEM), the health ministry (Luiz Henrique Mandetta, DEM), the general secretariat of the presidency (Gustavo Bebianno, PSL), and the ministry of citizenship (Osmar Terra, MDB); (7) the extreme-right deputies and senators elected in Bolsonaro's coattail; and (8) the loosely disciplined set of parties and legislators that follows the leadership of Rodrigo Maia, the chair of the Chamber of Deputies - this is the so-called "Centrão" or big center. From an ideological point of view, groups (1), (5), and (7) are far-right; the rest, center-right. The relative weight and hierarchical position of each group within the collection assembled by Bolsonaro are not known. This uncertainty has generated intense conflicts among them.

The high turnover in Bolsonaro's administration in 2019 is evidence of the tension between its cabinet members. At the general secretariat of the presidency alone, three individuals held its chair in 2019. The politician Gustavo Bebianno, 
after a fight with the President's son Carlos Bolsonaro (PSC), was replaced at the general secretariat of the presidency by General Floriano Peixoto Vieira Neto on February 18, 2019 (G1 2019). On June 21, 2019, General Floriano Peixoto was replaced by Jorge Antônio de Oliveira Francisco, a retired police officer and former deputy chief of legal affairs of the office of the President's staff (Jornal Nacional 2019). Another military casualty in Bolsonaro's cabinet was General Carlos Alberto dos Santos Cruz, dismissed from the government secretariat on June 13, 2019 (Folha de São Paulo 2019a). He was replaced by General Luiz Eduardo Ramos Baptista Pereira, who was the commander of the Southeast military region. Finally, on April 8, 2019, after being caught in the middle of the ideological dispute between the allies of Bolsonaro's guru, the self-proclaimed philosopher Olavo de Carvalho, and the so-called military wing of the government, education minister Ricardo Vélez Rodríguez was fired by Bolsonaro. The President then appointed to the office the professor and economist Abraham Weintraub, who already held a position at the office of the President's staff (G1 2019a).

After 12 months had elapsed since Bolsonaro's inauguration, there was no doubt about the minoritarian government strategy implemented by him. This strategy had two key dimensions: (a) as noted above, the decision not to form a stable legislative majority, although Bolsonaro has counted on the eventual support of ad hoc majorities; and (b) a way of communicating with the population that appeals, almost exclusively, to specific electoral niches and emphatically excludes others.

The first dimension is not new. Jânio Quadros and Fernando Collor also did not try to forge majorities in Congress. However, even though they frequently addressed certain groups of society - as every President does -, they always sought to court the majority support of the public opinion.

The second dimension, therefore, is one of the distinctive features of the Bolsonaro government, especially as compared to its predecessors installed since 1985. Note that this dimension does not boil down to courting Evangelical voters and praising gun-carrying people (Estadão 2019; Extra 2020). It also means the explicit scorn of those from whom the Bolsonaro administration withdraws public resources or means of legal protection. For example, women are amongst the President's favorite targets, female journalists are constantly made fun of during Q\&A sections, others have their past used against them journalist Miriam Leitão's torture under the military regime has been called a lie by the President multiple times -, and even world leaders and the wife of the French President were insulted by Bolsonaro (Folha de São Paulo 2019b). Large newspapers have been a systematic target. The President has gone as far as to threaten to boycott announcers from specific newspapers, use derogatory terms about the sexual preferences of journalists, question the quality of the work done by these vehicles and refuse their access to presidential events (Folha de São Paulo 2019c; Folha de São Paulo 2019d; O Globo 2019). The racial and sexual slurs are the favorite weapons of the President's rage against journalists. The President is the sole responsible for $58 \%$ of physical or moral assaults 
against journalists, according to the National Association of Journalists, FENAJ (Folha de São Paulo 2020). Opposition politicians and governors have been targets on many occasions (Estadão 2019a). In terms of the curtailing of rights and legal protection, the LGBTQ+ population is one of the most affected groups and were removed from the Human Rights directives during his first week in office (Poder 360 2019). Note that women are the majority of the electorate. Also, opinion polls show that the majority of the population and even Bolsonaro voters do not support his grotesque speeches against those groups. Here is eloquent evidence of his minoritarian strategy. No wonder Bolsonaro quickly lost public support throughout 2019, as shown in figure 1 below.

Figure 1. Bolsonaro's Approval Ratings in 2019

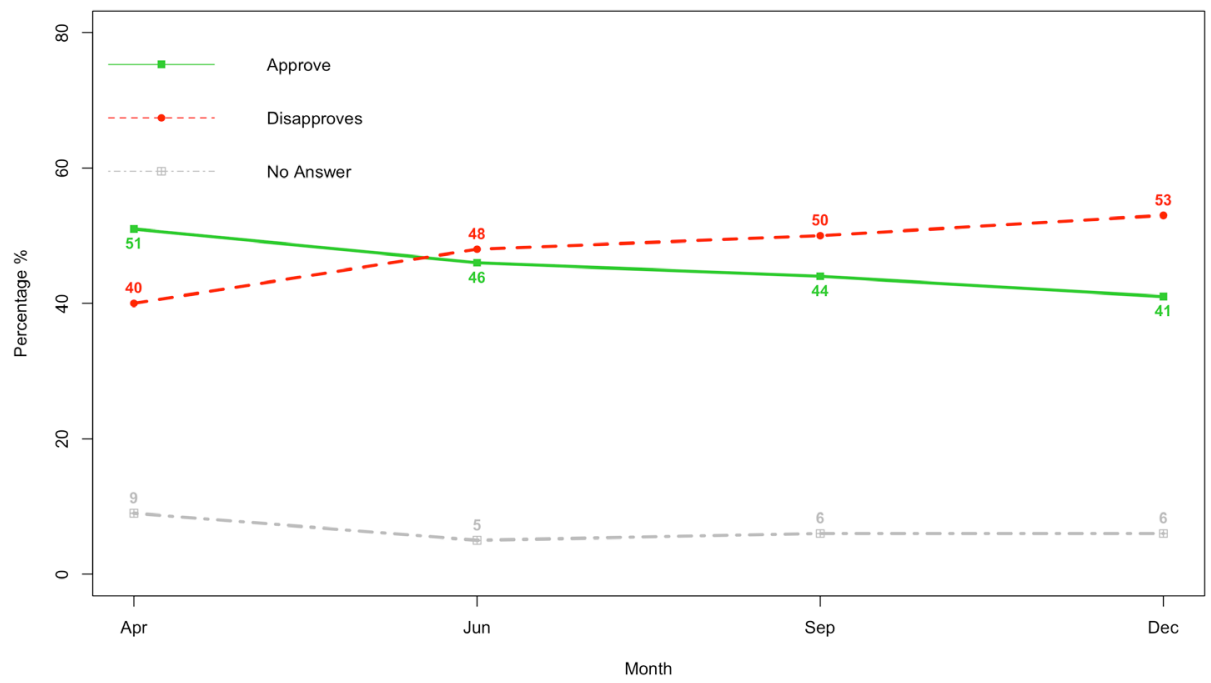

Source: CNI-IBOPE Inteligência (2019)

Given Bolsonaro's minoritarian strategy, by mid-May 2019, not surprisingly, Bolsonaro was already close to the four factors that, taken together, usually lead to the premature fall of presidents in Latin America (Hochstetler 2006; Pérez-Liñán 2014). The President did not form a legislative majority, the economy was in recession (the economy receded in the first quarter of 2019), there were street protests (students demonstrated against cuts in Education on May 15 and 30), and a major corruption scandal blew (involving his son senator Flávio Bolsonaro). ${ }^{3}$

\footnotetext{
The Federal Public Attorney implicated Flávio Bolsonaro in a massive corruption scandal, nicknamed the Queiroz case. Flávio was under investigation for misappropriation of funds from his office in the Rio de Janeiro State Assembly (he had been Rio de Janeiro state legislator in 2003-2019). According to financial records, Flávio employed ghost supporting staff who transferred their salaries to his personal account. The manager of said operation was Fabrício Queiroz, personal driver and bodyguard to Jair Bolsonaro (Oyama 2020: 124-125).
} 
Luckily for Bolsonaro, the last three factors were either not intense enough (particularly the street protests and the recession) or did not prosper. Besides, as of the end of May, the President reacted to almost all the facts and events described above. Bolsonaro supported street demonstrations in his favor; participated in a massive Evangelical march in São Paulo; went to stadiums to watch football matches in Brasilia and Rio de Janeiro; fired the military minister who sought to moderate him (General Santos Cruz) from the government secretariat, a vital ministry, on June 13, 2019; and tried to confront Congress a little less. Despite going against the anti-globalist rhetoric of his foreign minister Ernesto Araújo, Bolsonaro supported the approval of the Mercosur-European Union trade agreement, negotiated over 20 years. In contradiction to Bolsonaro's frequent attacks on the "old politics," he agreed to disburse budgetary funds to legislators on the eve of the first vote on the pension reform in the Lower House.

Let us delve deeper into Bolsonaro's relations with state governors to provide further evidence of what we call a minoritarian government strategy. Under past administrations, opposition governors were often punished by the federal executive, with the latter not granting them some federal budget transfers which allies received (Amorim Neto and Simonassi 2013). However, presidential rhetoric steered away from publicly humiliating these governors. That changed under Bolsonaro. Brazil's incumbent President is a master at adding insult to injury. He does so to keep mobilized a steadfast base of radical supporters that will remain loyal, regardless of his performance as head of State and government. Not surprisingly, Bolsonaro is now an avowed enemy of the rightwing governors of São Paulo, João Doria (affiliated with the PSDB), and of Rio de Janeiro, Wilson Witzel (affiliated with the PSC), Brazil's two largest state GDPs (CBN 2019; Exame 2019). However, Bolsonaro has been on good terms with the rightwing governor of Minas Gerais (Brazil's second-largest state in terms of population), Romeu Zema (affiliated with NOVO). ${ }^{4}$

As for Bolsonaro's relations with the press, as noted above, he had constant clashes with reporters during which he attacked them on a personal level. He refused to talk to any media outlet that criticized him and leveled open criticism at the quality of the work done by some newspapers. The President had a deeper appreciation for social media. It was his favorite means of communication with his supporters. His sons also indulged in the use of social media to promote the family's agenda, pick fights with alleged foes, and hit at allies (Oyama 2020: 211-231).

Regarding foreign relations, Bolsonaro ended the foreign policy Brazil had pursued in the past three decades during which the country had tried to 
become a global player with autonomous aspirations. ${ }^{5}$ The new administration set out to automatically align with the United States and pick fights and offend other non-far-right chief executives that, till recently, were essential diplomatic allies of Brazil. ${ }^{6}$ For example, Brazil was willing to give up some privileges and protections from the World Trade Organization (WTO), abandoning the developing country status, to gain a seat on the Organization for Economic Co-operation and Development (OECD) (Agência Brasil 2019). This was agreed on during Bolsonaro's very first visit to Donald Trump. Another offspring of that meeting was the concession of the Alcantara space center to the US: its location cheapens rocket launching by reducing fuel consumption. After 20 years of disagreements related to sovereignty issues, Bolsonaro's support was crucial for the agreement's approval (G1 2019b). While the President advocates the center's commercial opportunities, opposition groups claim that the agreement is not profitable and has little benefits in terms of technology transfer (Câmara dos Deputados 2019). A further transformation of Brazil's foreign policy is the now open support to Israel's claims over occupied territories in Palestine. Moreover, Bolsonaro plans on moving its embassy to Jerusalem, so as to endorse Israel's claims over the city, currently under dispute (Folha de São Paulo 2020a).

In addition, during the Amazon fires in August crisis, Bolsonaro also refused help from European leaders claiming it to be a domestic problem to be dealt with by the Brazilian government, and not by foreigners interested in stealing Brazil's natural riches (Oyama 2020: 183).

Bolsonaro's economic policy in 2019 was meant to create a pro-business environment. Economy Minister Paulo Guedes intended to remove barriers and reform the taxation system in order to make Brazil more attractive to foreign capital and use the latter to spur growth. The first step in this attempt at changing the Brazilian State was the social security reform, approved in late October 2019. However, Guedes failed to submit to Congress his plans to reform taxation and public administration. In support of his central plan, the economy minister introduced only smaller measures to facilitate entrepreneurship, access to unemployment funds, young adult employment, and debt renegotiation.

\footnotetext{
Bolsonaro's foreign policy is one of rupture and ideology. The president has broken longstanding traditions of the Ministry of Foreign Relations (Itamaraty). Under his administration, ideological alignment replaced meritocracy in the appointment of ambassadors, and a traditional pragmatic approach to issues gave way to an automatic alignment with the rightwing agenda pursued by Donald Trump (Lima and Albuquerque, 2019; Saraiva and Silva 2019; Gonçalves and Teixeira, 2020). Based on the political philosophy of Olavo de Carvalho, Bolsonaro has pursued an automatic alignment to US foreign interests. Though not unprecedented, this alignment reflects Bolsonaro's kinship to the international extreme-right movement, ideologically headed by Steve Bannon, Trump's chief strategist until mid-2018. Furthermore, much like Trump, Bolsonaro uses foreign policy as a platform to strengthen his hardcore supporters. Brazil's president often adopts concepts dear to the conservative agenda, such as the fight against "globalism" and "cultural Marxism" to draw his voters' attention (Lima and Albuquerque 2019).

6 Such as Argentina's Alberto Fernández, France's Emmanuel Macron, and Germany's Angela Merkel.
} 
Guedes's reform impetus ended up faltering in the second half of 2019 because of the government's weak legislative support and Bolsonaro's lack of enthusiasm for his minister's liberal agenda (in the European sense of liberal). However, there was some good news. The primary deficit was the lowest since $2014(-1,31 \%$ of GDP) (Valor Econômico 2020). Inflation remained relatively low by Brazilian standards, 3.74\% (IBGE 2020). Frustratingly, Brazil's economy only grew by $1.1 \%$ in 2019 (IBGE 2020a). Therefore, the unemployment rate remained high, reaching a peak of $12.7 \%$ in March but going down to 11\% by December (IBGE 2019; IBGE $2020 \mathrm{~b})$. This number is made even worse by the fact that $41 \%$ of jobs created in the period were informal or part-time employment (IBGE 2020c).

If economic growth in 2019 was frustrating, Bolsonaro pleased his voters by implementing a strong law-and-order policy. Under the command of Sergio Moro, the minister of Justice, the new government had three goals on public security: reduce organized crime, reduce violent crime, and combat corruption. Even though Congress dehydrated the anti-crime package before its enactment into law, Brazil saw a significant decrease in violent crimes. The most significant number was a $22 \%$ reduction in national homicide rates (G1 2019c). In addition, Moro led an effort to improve the use of intelligence to combat organized crime. Moreover, he imposed maximum security incarceration for criminal leaders, improved surveillance over drug dealers' money, authorized the use of national security forces in different crises in the states, and created the National Police Academy to help improve investigation skills of local police forces across the country. Yet, specialists in public security cast doubt on the role of Moro and the Federal government behind crime reduction. They alert that the downward trend on homicides, ongoing since 2016, might be the result of social change, and policies adopted by state governments (Exame 2019a; Estado de Minas 2019).

A note on Bolsonaro-military relations is in order. Public accounts for 2019 ended the year with a deficit of US\$ 2.65 billion above expectations (Economia UOL 2020). However, in December US\$ 1.9 billion was contributed to EMGEPRON - a state-owned company linked to Brazil's Ministry of Defense through the Brazilian Navy Command specialized in the management of projects of interest to the Brazilian Navy and the commercialization of defense products - for the construction of four corvettes for the Brazilian Navy (Economia UOL 2020). The expectation, within the Economy Ministry itself, was that the company would receive that amount over the next three years, and not all at once. Also, President Bolsonaro excluded the investment budget for the Ministry of Defense from being impounded in 2020, a decades-old demand of the Armed Forces. However, the Ministry of Education research funds will be cut in half, as should budgetary resources for federal universities. The protection given to the defense investment budget will imply cutting down expenses related to social spending. The 2020's budget of IBAMA - Brazil's environmental protection agency - was cut by almost a third, after having already been pruned in 2019 (Valor Econômico 2020a). Before the decisions taken at the end of 2019, Bolsonaro had already conferred significant 
advantages on the Armed Forces, by charging them only approximately US\$ 250 million a year as a social security economy measure and granting them a high pay increase (Valor Econômico 2020a). Furthermore, a newly enacted legal provision allowed retired military officers to work in the public sector with a pay increase of 30\% (Valor Econômico 2020a). Finally, approximately 2,500 military officers, active-duty or from the reserve - were appointed to sub-cabinet positions during 2019 (Valor Econômico 2020a).

The explanation for the impressive benefits obtained by the military in 2019 is obvious: the military are one of Bolsonaro's mainstays of political support. And, in Brazil, those who provide political support always receive, in exchange, appointments to federal administration positions and budgetary resources. Also, in the context of a painful fiscal adjustment, the government made another decision typical of the maligned "old politics": the costs of the fiscal adjustment must fall on the shoulders of sectors supposedly associated with the opposition. Hence, the harsh budget cuts that agencies linked to academic research, universities, and environmental protection suffered. Furthermore, as already mentioned, social policy expenditures are expected to be impounded throughout 2020 so to ensure the stability of the defense investment budget.

In short, by December 2019, Brazil found itself in one of the poles of the famous guns-versus-butter tradeoff. Decisions made by the executive and Congress in 2019 and the 2020 budget law signal the preference for defense spending over social spending. However, Brazil was not facing any serious threat to national security that justified such an option. On the contrary, the social situation was dire in 2019: high unemployment (annual average of $11.9 \%$ ), growing informality in the labor market (41\%), all kinds of urban crises, increasing inequality - in the second quarter of 2019, Brazil's score on the Gini index varied $0.11 \%$ as compared to the second quarter of 2018, according to Neri (2019) - and depressing educational indicators (IBGE 2019). Brazil, during the last economic recession in 2015-2016, achieved a record 0.627 Gini index, evidence that the government did not prepare to alleviate the impact of this crisis on the lower-income families. Furthermore, according to recent research, $52.6 \%$ of the adult population (over 25 years old) does not have a high school diploma (G1 2019d; IBRE 2019). Basic education in the country has improved over the past decade. However, it has not reached the alphabetization goals set in the 2014 National Education Plan, and most adults still struggle to conclude basic education programs (G1 2019d).

That said, a caveat on the role of the military in the Bolsonaro government is in order. Precisely because throughout 2019 the President undertook strenuous efforts to associate the military, notably the Army, with his presidency, the high command of that service perceived that such association could end up damaging its image and nature as an institution of the Brazilian state (as opposed to an instrument of the incumbent government). The Army High Command also became concerned with the politicization of active-duty officers and rankand-file by "Bolsonarismo." A wave of political and partisan demonstrations in social media in favor of Bolsonaro and against other politicians and parties 
since 2018 by members of the military profession influenced the decision of the Army commander, General Edson Leal Pujol, to create rules against this digital activism (Estadão 2019b). In 2019 this was the most significant attempt at separating the so-called institutional Army from the military serving or supporting the Bolsonaro administration.

Finally, also noteworthy is Bolsonaro and his sons' relationship with Brazil's Supreme Court (STF), lambasted by them on several occasions. In 2018, during Bolsonaro's campaign, a video where Eduardo Bolsonaro implied that it was incredibly simple to shut down the Supreme Court went viral and caused controversy in the country (Folha de São Paulo 2018). Furthermore, Bolsonaro and his sons have criticized several decisions by the Brazilian Supreme court. For instance, in March 2019 Bolsonaro posted a video of Eduardo Bolsonaro criticizing STF rulings on the anti-corruption "Car Wash Operation" (Operação Lava-Jato), and in June 2019 Bolsonaro announced in a press conference that treating homophobia as a crime in Brazil was a mistake by the STF and that he intended to appoint a "terribly evangelical" member to the Court (Correio Braziliense 2019; Estado de Minas 2019a). More recently, in October 2019 he had to publicly apologize to the STF after sharing a video in his social media where the institution was depicted as a hyena - he was a lion under attack - alongside opposition politicians, members of the press and other Brazilian institutions (Jornal do Brasil 2020).

\section{BOLSONARO'S BROTHERS IN ARMS: JÂNIO QUADROS AND FERNANDO COLLOR}

In this section, we compare Jair Bolsonaro with his two Brazilian rightwing populist predecessors, Jânio Quadros, and Fernando Collor. To do so, we have selected thirteen dimensions to analyze the three presidents systematically. The dimensions have to do with political context and attributes (the previous administration's type of cabinet; the economic situation in the year of the election; the state of the party system; the state of the international system, main campaign topics raised by the President; social and geographic patterns of voting for the winning candidate; the type of cabinet appointed in the first year in office, the government's legislative situation, and the President's relations with state governors); with policy (main lines of economic policy and foreign policy); and with institutional relations (with the Armed Forces, the press, and the Supreme Court, and implicit and explicit threats made by the President to institutions and the Constitution).

The previous section already applied most dimensions to Bolsonaro in 2019. But, we have yet to discuss the states of the economy, party system, and the international system in 2018. Now we first set out to dissect Quadros and Collor based on the secondary literature. Table 1 below summarizes our findings on Brazil's three rightwing populists. 
Table 1.13 analytical dimensions of Brazil's Three Rightwing Populist Presidents - Jânio Quadros, Fernando Collor, and Jair Bolsonaro

\begin{tabular}{|c|c|c|c|}
\hline President & $\begin{array}{l}\text { Jânio Quadros } \\
\text { (1961) }\end{array}$ & $\begin{array}{c}\text { Fernando Collor } \\
\text { (1990) }\end{array}$ & $\begin{array}{l}\text { Jair Bolsonaro } \\
(2019)\end{array}$ \\
\hline \multicolumn{4}{|c|}{ Political context and attributes } \\
\hline $\begin{array}{l}\text { 1) Previous administra- } \\
\text { tion's type of government }\end{array}$ & $\begin{array}{l}\text { Right-leaning majo- } \\
\text { rity coalition }\end{array}$ & $\begin{array}{l}\text { Right-leaning majority } \\
\text { coalition }\end{array}$ & $\begin{array}{l}\text { Right-leaning majori- } \\
\text { ty coalition }\end{array}$ \\
\hline $\begin{array}{l}\text { 2) The economic scenario } \\
\text { in the election year }\end{array}$ & $\begin{array}{l}\text { High inflation but } \\
\text { with high economic } \\
\text { growth in } 1960\end{array}$ & $\begin{array}{l}\text { Hyperinflation with } \\
\text { moderate growth and } \\
\text { low unemployment in } \\
1989\end{array}$ & $\begin{array}{l}\text { Low inflation, very } \\
\text { low growth, and high } \\
\text { unemployment in } \\
2018\end{array}$ \\
\hline
\end{tabular}

3) State of the party sys- Institutionalization Highly volatile and in- Growing institutiotem in the election year was growing in choate by 1989

the second half of nalization since 1994 the 1950s, but conservative parties but uneven; largest were quickly losing parties in disarray by 2018 ground by 1960

4) State of the internatio- The peak of the End of the Cold War nal system in the election Cold War in Latin year

America due to the Cuban Revolution

End of the US hegemony, the rise of China, the rise of rightwing nationalist populism in the West

5) Patterns of voting for Quadros, a popu- Collor, elected with an Bolsonaro, a candithe candidates in the list candidate with appeal to the masses date of rich, white, 1960, 1989 and 2018 elec- strong support from against the left, suppor- Evangelical, and tions (socially and geo- the middle class ted by low income and Northern, Midwesgraphically) and rich voters; had low education voters; tern, and Southern strong backing from strong backing from voters; had strong conservative politi- political elites and bu- backing from the pocians, the military, siness groups; his vo- lice and armed forces' and big business; ters were concentrated rank-and-file, retired his voters were con- in the North, Midwest, military officers, as centrated in the Sou- and Northeast theast and South

well as conservative religious groups, and agribusiness

6) Main campaign topics raised by the winner

Corruption of the Defense of administraCorruption, law and previous govt, in- tive moralization cen- order, pro-market flation, high cost of tered on allegations of economic liberalism, living, the irrespon- corruption against the defense of family vasible behavior of the Sarney government and lues, and anti-socia"flying president of the fight against the lism

(JK)," cleaning of privileges of the civil public administra- service; the modernization, the need to put tion of the country, with an end to the PSD- emphasis on reducing PTB coalition the presence of the state in the economy

7) Cabinet formation and Mostly partisan Mostly non-partisan Mostly non-partisan government's legislative ministers but in ministers; in the mino- ministers; highly misituation and relations the minority in rity in Congress, weak litarized cabinet; in with state governors Congress; Quadros support from governors attempted to have good relations with the minority in Congress; very hostile relations with key governors governors 
Policy dimensions

8) Economic policy in the Focus on domestic Heterodox inflation-fi- Orthodox fiscal adfirst year of administra- economic stability ghting program; priva- justment

tion to increase exter- tization and trade libenal credibility and ralization.

regain possible partnerships with foreign investors to boost growth.

9) Main foreign policy Independent vectors fo- Some alignment with Automatic alignment the US, favored Merco- with the US, antagosur, ended nuclear pro- nism with leftwing gram governments in LA and core EU countries

Institutional Relations

10) Relations with the Ar- Close with the con- Distant in his first year Very close, intimate med Forces servative faction in office; Collor disof the military, but mantled some military conflictive and pu- agencies and ministries nitive with nationalist officers

11) Relations with the Quadros tried to Very tense; Collor orde- Radically antagonispress restrict freedom of red the Federal Police tic the press to invade the headquarters of Folha de São Paulo and sued the newspaper later

12) Relations with the Su- Secondary literatu- Suffered important de- President and his preme Court re registers no signi- feats at the Supreme sons openly conficant fact Court, but accepted temptuous of the Suthem preme Court

13) Implicit and explicit Openly contemp- Confronted Congress Openly and frequentthreats to institutions and tuous of Congress the Constitution with an avalanche of ly threatened institupresidential decrees of tions questionable constitutionality, but did not openly threaten institutions

\section{Jânio Quadros}

The President who preceded Quadros was Juscelino Kubitschek. Throughout his five years in office, Kubitschek led a right-leaning (or center-right) majority coalition government. This administration is considered the most successful of the 1946-1964 democratic period because of its relative political stability and the high rates of growth (it was able to promote $8.1 \%$ average growth). In 1960 the economy was still growing at a rate of 9.4\% (Giambiagi et al. 2011: 28). However, it was not without problems. Brazil was suffering from high inflation (oscillating between $30 \%$ and $40 \%$ in 1960), a budget deficit around one-third of the total revenues of the national government, and the deterioration of the 
current account (exports fell by more than 10\% between 1955 and 1960) (Giambiagi et al. 2011: 28; 39).

Regarding the state of the party system, some authors contend that Brazil was going through a representation crisis because urban voters in the country's speedily growing cities no longer found the major conservative parties - the PSD and UDN - attractive, thus opening political space for populist and leftwing leaders and organizations (Soares 1973; Souza 1976; Benevides 1981). In fact, in the 1958 congressional elections, the PSD and UDN almost lost their traditional legislative majority. Lavareda (1991), on the other hand, argues that the Brazilian party system was maturing and better-reflecting voter preferences, which were beginning to gain improved legislative representation. As a consequence, the PTB, a center-left party, saw its electorate grow and, for the first time, obtained more than $20 \%$ of the lower chamber seats. Meanwhile, the urban middle classes, keen on fighting inflation and corruption, also saw its political heft increase. Despite its relative economic and political success, the Kubitschek administration was tainted by grave corruption scandals and accusations associated with the building of Brazil's new capital city, Brasilia (Dicionário Histórico-Biográfico Brasileiro, entry on Juscelino Kubitschek). Moreover, high inflation mightily contributed to foul the mood of vast sectors of voters. Against this backdrop, Quadro's reputation as a politician who was independent of parties and keen on cleaning the government spread.

As for the state of the international system in 1960, recall that the Cuban Revolution had finally been successful the previous year. Latin America was thus reaching the height of the Cold War. These events also helped to polarize Brazilian politics.

Affiliated with the tiny PTN (National Labor Party), Jânio Quadros won the presidential race of October 3, 1960, with $48 \%$ of the votes (at that time Brazil adopted plurality rule for presidential elections). The votes obtained by Quadros in Rio de Janeiro, Rio Grande do Sul, Minas Gerais and São Paulo amounted to $78 \%$ of his total tally. This means that Brazil's largest and wealthiest states had primarily elected him. At the voter level, Soares (1962) provides survey data showing that Quadros was the most voted presidential candidate among respondents with the highest levels of income and schooling.

In his campaign, Quadros promised to restore Brazil's parlous public finances to health, while seeking to reconcile the fight against inflation with high rates of economic growth. Moreover, Quadro's platform pushed for the strengthening of Petrobras (Brazil's state-owned oil company), the fight against corruption, and an independent foreign policy that included both the resumption of diplomatic relations with socialist countries and the control of profits sent abroad by multinational firms.

As for the political makeup of his government, Quadros appointed an all-inclusive cabinet, including politicians from the UDN, PSD, PTB, and three minor 
parties, from both the left and right and a few non-partisan ministers (18\% of his civilian ministers). Despite having ministers affiliated with the largest parties, Quadro's cabinet did not command a legislative majority. The President openly despised political parties and the legislative branch, calling Congress "a club of idle people" (Benevides 1981: 38). According to Chaia (1991: 226), "He believed that he could govern alone, counting only on popular support." Interestingly enough, Quadros organized frequent meetings with governors in their states, thus creating a base of political support and a decision-making arena outside the national legislature (Benevides 1981: 36).

His economic policies included an exchange rate reform, spending cuts, a decrease in the defense budget, a decrease in diplomats' salaries, and the enforcement of strict rules to Brazilian public agencies. In August of 1961, the month of his resignation, given the rising cost of living caused by the exchange rate reform and the difficulties found in reconciling his finance minister's anti-inflation program with economic growth, Quadros came to lambast Clemente Mariani, the finance minister.

Quadro's foreign policy was surprising. While his domestic policies were conservative and entirely accepted by the United States, his diplomacy followed an independent path, being open to relations with all countries. Accordingly, Quadros set out to establishing ties with the nations of the socialist bloc and expand Brazil's presence in Africa.

As for Quadros's relations with the Armed Forces, to the three military ministries (Army, Navy, and Air Force) and the main military positions, he appointed officers connected to the conservative wing of the military as opposed to the nationalist faction thereof. According to Chaia (1991: 228), Quadros punished nationalist officers by transferring them to posts far away from the capital and most prominent cities. At the beginning of his term, Quadros set out to create an image of innovation in mores and public morality. To do so, he delegated essential roles to the military in his quest to evaluate the performance of public agencies. According to Benevides (1981: 36), one of the main reasons why some sectors in Congress began to be hostile to Quadros was precisely the privileged political space he had granted the Armed Forces.

Regarding the press, although Quadro's campaign program defended all civic liberties, it also contained a caveat: such liberties should be disciplined so as not to oppose the interests of the community. Not surprisingly, during his short tenure, he restricted civic liberties by imposing censure on some news about his administration. For example, the operation of the radio station Jornal do Brasil was suspended because the station had divulged news about a military agreement between Brazil and Argentina. Congress and the press openly criticized this move. Quadros also ordered that foreign news agencies were investigated because he considered that the latter published biased news about Brazil (Chaia 1991: 227). 
As for Quadros's relations with the Supreme Court, the secondary literature does not register any relevant fact or event.

Finally, after six months in office, Quadros began to mature the idea of promoting an extensive constitutional reform. In mid-August 1961 his minister of Justice, Pedroso Horta, said the following to Carlos Lacerda, one of the UDN leaders: "Jânio thinks that it is impossible to govern with Congress and intends to reform the Constitution to strengthen the Executive Power," clarifying that this project would require the establishment of a state of exception (Dicionário Histórico-Biográfico Brasileiro, entry on Jânio Quadros). This explicit threat was quickly rejected by party and congressional leaders. Then, in an ill-advised move designed to force Congress to grant him exceptional powers, Quadros tendered his resignation in hopes that Congress would not accept it and would plead him to return to his office. His departure, however, was promptly accepted. Thus ended the Quadros presidency.

\section{Fernando Collor}

Before taking the presidential office on March 15, 1990, Fernando Collor was preceded by José Sarney, the first civilian president after 21 years of military rule in 1964-1985. Sarney had been the vice-mate on Tancredo Neves's ticket for the indirect presidential election of January 15, 1985. Sarney ended up wearing the presidential sash because Neves fell ill on the eve of being sworn in President, and came to die on April 21, 1985. Sarney governed with a right-leaning (or center-right) majority coalition composed of the PMDB and PFL.

The economic scenario in 1989 was marked by hyperinflation, with the official monthly index reaching above $80 \%$, amounting to $1.000 .000 \%$ over the 1985 1989 period. However, in 1989 the country featured moderate growth rates $(3.3 \%)$ and low levels of unemployment (3.3\%) (Giambiagi et al. 2005: 132; Giambiagi et al. 2011: 257).

As for the state of the party system in 1989, it was highly volatile and inchoate (Mainwaring and Scully 1995; Mainwaring 1999; Mainwaring et al. 2018). After all, Brazil was still in the early stages of the transition to democracy in 1985 and the promulgation of the new Constitution of 1988. Suffice it to say that the first round of the presidential election in 1989 included no less than 25 candidates.

Regarding the state of the international system in 1989, it was marked by the fateful fall of the Berlin Wall and the end of the Cold War. The defeat of the Soviet Union in the Cold War weakened the appeal of the left throughout the world, Brazil included.

In his presidential bid, Collor presented himself as an outsider, even though he was part of a traditional family of politicians from Alagoas. His previous political career included the holding of the following offices: mayor of Maceió in 
1979-1983, federal deputy in 1983-1987, and governor of Alagoas in 1987-1989. He ran on the ticket of the PRN (National Reconstruction Party) - created in 1985 with the label Party of the Youth and rechristened in 1989 as PRN - with which he became affiliated only in February 1989. His campaign was endorsed by conservative political elites, big media, and financial and business groups. According to Mainwaring (1999: 117), Collor fared much better among the poor than among higher-income groups and did best among the least educated and worst among the best educated. In terms of regional concentration of votes, Collor obtained his most significant shares in the North $(70.5 \%)$ and Midwest $(63.2 \%)$, smaller but majority shares in the Northeast $(55.7 \%)$ and Southeast (50.5\%), and lost in the South (48.3\%) (Lima Júnior 1999: 18).

Collor's campaign program was mostly focused on fighting systemic corruption in politics, cleaning the government, and putting an end to the privileges of bureaucrats. He emphasized the need for modernizing Brazil's public administration and shrinking the role of the state in the economic domain.

Collor's first cabinet was mostly composed of non-partisan ministers (60\%) and co-opted politicians from the centrist PMDB and the rightist PFL and PRN. It was a minority administration which resulted in a permanently conflictive relationship with Congress. Later on, years after being impeached, Collor would acknowledge that not coming to terms with political parties was his biggest mistake (Estadão 2019). Moreover, Collor also had weak support from the state governors, particularly from the governors of Brazil's largest states, São Paulo, Minas Gerais, and Rio de Janeiro, ruled by the PMDB, heavily defeated by Collor in the presidential election (the PMDB's presidential candidate, Ulysses Guimarães, got only $4.4 \%$ of the national vote). In 1991, however, Collor would strike a deal with the new governor of Rio de Janeiro, Leonel Brizola, elected in late 1990, and his party, the center-left PDT. Indeed, the cooperation between Collor and the PDT would provide the President with relevant legislative support throughout 1991 (Amorim Neto et al. 2003: 571).

As for Collor's economic policy in his first year in office, the day after his inauguration he presented the country a highly heterodox economic stabilization plan that included the replacement of the existing currency, the freezing of $80 \%$ of private assets for 18 months, a high tax on all financial transactions, the indexation of taxes, the abolition of most fiscal incentives, an increase in the prices charged by public utilities, the adoption of a floating exchange rate, a temporary freeze on wages and prices, the closing down of dozens of government agencies, and plans for the laying off of approximately 300.000 public employees. Other important economic measures were in tune with the Washington consensus, such as trade liberalization and the privatization of stateowned enterprises.

On foreign policy, as already mentioned, some of Collor's economic measures were aligned with the preferences of the United States and those of the US-dominated IMF. He also ended Brazil's nuclear program, which certain- 
ly pleased Washington. However, the most relevant move of his diplomacy was the Asunción Treaty, signed in March 1991, establishing a common market among Argentina, Brazil, Paraguay, and Uruguay, the bloc that came to be called Mercosur.

Regarding Collor's rapport with the Armed Forces, interestingly enough, he kept a distant relationship with the military in his first year in office. In fact, Collor enacted important reforms in this area. Right at the beginning of his term, he, in a bold move, extinguished the hated National Intelligence Service (SNI) bequeathed by the military regime and the Military Staff of the Presidency and withdrew the ministerial rank of the Armed Forces General Staff.

As for the press, right at the very beginning of his term Collor would invite the press corps to cover his non-official activities, such as radical sports practice, in an attempt at creating the image of a strong man. However, a few days after his inauguration, the Federal Police invaded the Folha de São Paulo newspaper headquarters. The Collor government defended the invasion based on alleged wrongdoing in advertising fees (Villa 2016: 43). In August 1990, news began to circulate reporting that Collor had hired, without bidding, news agencies that had worked in his presidential campaign. In an unprecedented move in Brazilian history, Collor started a lawsuit against Folha de São Paulo, whom he accused of having slandered him when the newspaper published that news (Dicionário Histórico-Biográfico Brasileiro, entry on Fernando Collor).

On Collor's relations with the Supreme Court, the secondary literature only mentions some defeats he suffered at the court but reports no undue friction between the executive and judicial branches. Newspaper articles gathered from the time support our belief that Collor had a correct relationship with the STF, even though the judiciary constituted the main resistance point for his heterodox measures (O Globo 1990; O Globo 1990a; O Globo 1990b; O Globo1999c).

Finally, as for implicit and explicit threats to institutions and the Constitution, while Collor confronted Congress and the Supreme Court with an avalanche of presidential decrees of questionable constitutionality, he did not openly threaten the two institutions. As mentioned above, he did threaten the press in 1990.

After the failure of his heterodox economic stabilization plan by early 1991, Collor prematurely became a lame-duck president, although his term would end officially only in January 1995. In March 1991 his popularity plummeted to less than 30\%. In April that year, the Chamber of Deputies almost passed a law limiting the President's decree powers, in a clear message to the chief executive. Accordingly, Collor tried to react to his growing isolation. In May 1991, he appointed an elder statesman, Marcílio Marques Moreira, a respected diplomat and financier, to the ministry of finance, an appointment well received by the market and Congress. In addition, Collor considerably reduced the issuance of presidential decrees, which he had abused in 1990. Even so, 
with the economy stagnant, inflation very high, popularity steadily falling, and growing allegations of corruption involving the President's camarilla, the political situation of Collor remained very precarious. In April 1992 he gave his last shot: he appointed a cabinet characterized by the delegation of power to important party leaders (notably Jorge Bornhausen, affiliated with the PFL) and other elder statesmen (Célio Borja, Hélio Jaguaribe and Celso Lafer), great public men who combined renowned expertise and strong ties with political, business, cultural and academic elites. At first, this cabinet was capable of stabilizing the government's political situation. However, in May 1992, Pedro Collor, a brother of the President, made serious accusations against the chief executive. From then on, Collor went down the drain until he was removed from office on October 2, 1992.

\section{THE DISTINGUISHING FEATURES OF BOLSONARO VIS-À-VIS QUADROS AND COLLOR}

Now we proceed to identify the similarities and differences among Quadros, Collor, and Bolsonaro in order to pin down the unique features of the latter. To do so, we have yet to briefly describe national and international conditions in 2018 and the critical attributes of Bolsonaro's campaign and core voters.

As already noted, in 2018, Brazil was under the right-leaning coalition cabinet led by President Michel Temer, affiliated with the centrist MDB. Temer was an extremely unpopular chief executive whose image had been tainted by grave corruption scandals (Duque and Smith 2019). While the country's economic performance in 2018 was not too bad (inflation was low [3.66\%], and Brazil's high public debt and deficit began to decrease slowly), output growth remained stagnant (1.1\%), and high unemployment persisted (12.3\%) Although Brazil's party system institutionalization had grown in 1994-2014 (Mainwaring et al. 2018), by 2018 the country's main parties - the PT, PSDB, and MDB - were in utter disarray (Almeida 2019: 92; Duque and Smith 2019). As with Quadros and Collor, these conditions favored the rise of Bolsonaro.

As for the international system, it was marked by the disruptive presidency of Donald Trump, the growing rivalry between the US and China, and the weakening of international organizations. The fact that Washington was, and still is, under the rule of an extreme-right populist obviously helped Bolsonaro's winning presidential bid. Bolsonaro's campaign platform focused on fighting corruption, law-and-order, pro-market economic policies, criticizing China's presence in the Brazilian economy, the defense of family values, and anti-socialism or, in Brazil's political jargon, antipetismo. ${ }^{7}$ 
During his campaign, Bolsonaro received strong backing from the police and Armed Forces' rank-and-file and retired military officers, as well as conservative religious groups, financial investors, and agribusiness. At the individual voter level, according to Almeida and Guarnieri (2020), "Bolsonaro's core voter was a young man ( 25 to 34 years old), white, with high family income between 20 and 50 minimum wages, Evangelical and resident of the North, South and Midwest regions of Brazil. The likelihood that someone with this social profile declared his intention to vote for Bolsonaro was $89.5 \%$, in June 2018 , while the overall average was $19 \%$. In October 2018, the probability rose to $95 \%$, e.g., almost every person of that group would vote for the PSL candidate." It is noteworthy that Evangelicals form a heterogeneous group, and while Bolsonaro had more vocal support from Pentecostals and Neopentecostals during his campaign, he seems to remain most popular with the latter stream (BBC 2018; Época 2019).

That said, the following are the common core features among Brazil's three rightwing populist presidents: (i) their election was held under discredited right-leaning (or center-right) coalitional presidencies associated with corruption and bad economic management; (ii) all were political insiders who ran as mavericks against a political establishment portrayed as corrupt; (iii) in the year of their election they were affiliated with very small parties, their political careers having been characterized by a weak attachment to any party; ${ }^{8}$ (iv) they shrewdly took advantage of the political space opened by the marked decline in the largest parties' popular support; (v) the three were unwilling to form a legislative majority in their first year in office and, consequently, had very conflictive relations with Congress; and (vi) they all had bad relations with the press, although Bolsonaro is in a class of his own on this count.

Now the features that Bolsonaro shares with only one of the two other rightwing populists. Like Quadros's, Bolsonaro's core voters are richer and more concentrated in the southern half of Brazil. Like Quadros, Bolsonaro has a keen concern with moral issues. Like Collor's, Bolsonaro's cabinet in his first year in office was packed with non-partisan ministers. Like Quadros's, Bolsonaro's economic policy in 2019 was orthodox. All told, Bolsonaro is closer to Quadros than to Collor.

Finally, we now pin down the unique attributes of Bolsonaro in addition to his public communication approach described in the second section of the article. First, he is the President who has drafted by far the highest number of military officers into cabinet- and sub-cabinet rank positions not only as compared to Quadros and Collor but also as compared to all presidents sworn in since 1985.

According to Carrera's (2012) typology of Latin American outsiders, Quadros, Collor, and Bolsonaro should also be classified as mavericks (professional politicians without an established party). Therefore, the three Brazilian presidents are different from full outsiders like Peru's Alberto Fujimori or Ecuador's Rafael Correa and from amateurs (politicians who are new to politics but compete in traditional parties) like El Salvador's Mauricio Funes or Argentina's Daniel Scioli. 
Note that Quadros also tried to involve the military with his government closely. However, in the early 1960s, the Brazilian Armed Forces were politically divided between a conservative and a nationalist faction (Martins Filho 2003). This is not the case nowadays. This means that Bolsonaro can count on much more robust support from the barracks. In addition, Bolsonaro is the only one among the three rightwing populists who has no political relations whatsoever with the left. Quadros appointed two politicians from leftwing parties to his cabinet (Brígido Tinoco, affiliated with the Brazilian Socialist Party, to the Ministry of Education; and Francisco de Castro Neves, affiliated with the Brazilian Labor Party, to the Ministry of Labor). As noted above, in his second year in office, Collor struck a political deal with a leftwing party, the PDT, and a leftwing governor, Leonel Brizola. In this sense, Bolsonaro is the most extremist of the three. Bolsonaro is also the most pro-American President not only among the three rightwing populists but since 1985. This has obviously to do with the fact that an extreme-right populist has governed the US since 2017. Among the three Brazilian rightwing populists, Bolsonaro is the one who had the most hostile relationship with the Supreme Court. Finally, Bolsonaro is the most pro-Evangelical President ever in Brazilian history.

\section{CONCLUSION}

Our identification of the similarities among Quadros, Collor, and Bolsonaro as regards their career background, the origin of their presidencies, presidential campaign and election, and their first year in office provides compelling evidence of Weyland's definition of Latin American populism: the three presidents' common features are exclusively political - having to do essentially with their hostility to party and legislative institutions. Their policy differences are ample, and their relations with the Armed Forces, the left, the judicial branch, and the US also vary widely. In this sense, Bolsonaro, in 2019, is a classical Latin American populist.

Bolsonaro's first year in office was extraordinarily conflictive and confusing, just like those of Quadros and Collor. Thus, their story is the same. But Bolsonaro sings a different song, a blend of martial notes and Evangelical chants. The implications of this cacophony are grave. Civil-military relations have been unhinged, after 20 years of relative progress in terms of their democratization, as described in detail by Pion-Berlin and Martinez (2017). Therefore, political control of the military has been severely eroded in a country that only 36 years ago was under a military regime initiated in 1964.

By its turn, the rock-solid support provided by conservative Evangelical voters to Bolsonaro allowed him to permanently resort to four tactics in conducting his relations with the other branches of government and many sectors of society: (1) to transfer the costs of major presidential decisions to others - this was made crystal-clear during the approval of the pension system reform, when the 
chair of the Chamber of Deputies, Rodrigo Maia, took the lead in mobilizing support for the reform, not the President; (2) to identify alleged enemies who conspire against him (inside and outside his administration, including his ministers); (3) to attack the alleged enemies with grotesque and churlish language, and (4) to create smoke screens to mask facts associated with his administration that generate bad news. If throughout 2019 it was already staggering to see that Brazil had a robotic president, who shocked but was never surprising, the country is now facing a tragedy, as it is with that limited repertoire that Bolsonaro has been dealing with the pandemic of the Covid-19 and a looming deep economic recession. No wonder since late April 2020 Bolsonaro's fall has become the main issue on Brazil's political agenda. Same old story?

\section{REFERENCES}

Agência Brasil. 2019. "Brasil Abrirá Mão de Direitos na OMC para Ingressar na OCDE." Retrieved 23 June, 2020 from https://agenciabrasil.ebc.com.br/internacional/noticia/2019-03/brasil-abrira-mao-de-direitos-na-omc-para-ingressar-na-ocde

Almeida, Acir. 2020. "Relações Executivo-Legislativo e Governabilidade à Luz da Crise da Covid-19." Diretoria de Estudos e Políticas do Estado, das Instituições e da Democracia (DIEST), Nota Técnica $N^{\circ}$ 34. Brasilia: IPEA.

Almeida, Maria Hermínia T. 2019. Os Anos de Ouro: Ensaios Sobre a Democracia no Brasil. Lisbon: Livros Horizonte.

Almeida, Maria Hermínia T. and Fernando Guarnieri. 2020. "The Unlikely President: The Populist Captain and His Voters." Revista Euro Latinoamericana de Estudios Sociales y Politicos (forthcoming in March 2021).

Amaral, Oswald E. 2020. "The Victory of Jair Bolsonaro According to the Brazilian Electoral Study of 2018." Brazilian Political Science Review 14 (1): e0004 -1/13.

Amorim Neto, Octavio, Gary W. Cox and Matthew D. McCubbins. 2003. "Agenda Power in Brazil's Câmara dos Deputados, 1989-98." World Politics 55(4): 550-578.

Amorim Neto, Octavio and Andrei Gomes Simonassi. 2013. "Bases Políticas das Transferências Intergovernamentais no Brasil (1985-2004)." Revista de Economia Política 33(4): 704-725.

BBC. 2018, October 23. “Eleições 2018: Os Valores e 'Boatos' Que Conduzem Evangélicos a Bolsonaro." Retrieved April 10, 2020 from https://www.bbc.com/portuguese/brasil-45829796

Benevides, Maria Victoria. 1981. O governo Jânio Quadros. São Paulo: Editora Brasiliense.

Câmara dos Deputados. 2019, October 22. "Câmara Aprova Acordo entre Brasil e EUA Sobre Uso da Base de Alcântara." Retrieved 23 June, 2020 from https://www.camara.leg. $\mathrm{br} /$ noticias / 603242-camara-aprova-acordo-entre-brasil-e-eua-sobre-uso-da-base-dealcantara/

Carreras, Miguel. 2012. "The Rise of Outsiders in Latin America, 1980-2010: An Institutionalist Perspective." Comparative Political Studies 45(12): 1451-1482.

CBN. 2019, November 04. "Na Briga Entre Bolsonaro e Witzel, o Rio Fica em Segundo Plano." Retrieved March 09, 2020 from https://cbn.globoradio.globo.com/media/audio/280454/na-briga-entre-bolsonaro-e-witzel-o-rio-fica-em-se.htm

Chaia, Vera Lúcia M. 1991. A liderança política de Jânio Quadros (1947 a 1990). Ibitinga: Humanidades.

CNI-IBOPE Inteligência (2019). “Avaliação do Governo Federal." Job0446/2019. Brasil.

Correio Braziliense. 2019, June 14. "Bolsonaro Critica STF e Volta a Defender Indicação de Ministro Evangélico." Retrieved March 06, 2020 from https://www.correiobrazil- 
iense.com.br/app/noticia/politica/2019/06/14/interna_politica,762972/bolsonaro-critica-stf-e-volta-a-defender-indicacao-de-ministro-evangel.shtml

Dicionário Histórico-Biográfico Brasileiro. N.D. "Entry on Juscelino Kubitschek de Oliveira." CPDOC/FGV. Retrieved February 10, 2020 from http:/ /www.fgv.br/cpdoc/acervo/ dicionarios/verbete-biografico/juscelino-kubitschek-de-oliveira

Dicionário Histórico-Biográfico Brasileiro. N.D. "Entry on Jânio Quadros." CPDOC/FGV. Retrieved February 10, 2020 from http://www.fgv.br/cpdoc/acervo/dicionarios/ verbete-biografico/janio-da-silva-quadros

Dicionário Histórico-Biográfico Brasileiro. N.D. "Entry on Fernando Collor." CPDOC/FGV. Retrieved February 10, 2020 from https://www.fgv.br/cpdoc/acervo/dicionarios/ verbete-biografico/collor-fernando

Duque, Debora and Amy E. Smith. 2019. “The Establishment Upside Down: A Year of Change in Brazil." Revista de Ciencia Política 39(2): 165-189.

Economia UOL. 2020, January 29. “Governo Central Tem Déficit Primário de R \$95,065 Bi em 2019, Melhor Desde 2014." Retrieved April 15, 2020 from fhttps:/ /economia.uol.com. $\mathrm{br} /$ noticias/reuters/2020/01/29/governo-central-tem-deficit-primario-de-r95065bi-em-2019-melhor-desde-2014.htm

Época. 2019, July 08. "Evangélicos Neopentecostais São os Mais Satisfeitos Com o Governo." Retrieved April 15, 2020 from https:/ /epoca.globo.com/brasil/evangelicos-neopentecostais-sao-os-mais-satisfeitos-com-governo-23792398

Estadão. 2019, June 15. "Bolsonaro Defende Armar a População Contra Golpes de Estado." Retrieved May 05, 2020 from https://politica.estadao.com.br/noticias/geral,bolsonaro-defende-armar-a-populacao-contra-golpes-de-estado,70002875064

Estadão. 2019a, July 20. "Bolsonaro Diz Que Governadores do Nordeste Têm Ideologia e Tentam Manipular Eleitores." Retrieved April 17, 2020 from https://politica.estadao.com.br/noticias/geral,bolsonaro-diz-que-governadores-do-nordeste-tem-ideologia-e-tentam-manipular-eleitores,70002930331

Estadão. 2019b, July 20. “Exército Enquadra Tuítes Políticos de Militares da Ativa." Retrieved June 23, 2020 from https://politica.estadao.com.br/noticias/geral,exercito-enquadra-tuites-politicos-de-militares-da-ativa,70002930364

Estadão. 2019c, December 17. "30 Anos Depois, o Que Pensa Fernando Collor da Eleição de 89?" Retrieved April 17, 2020 from https://politica.estadao.com.br/noticias/geral,30-anos-depois-o-que-pensa-fernando-collor-da-eleicao-de-89,70003127868

Estado de Minas. 2019 October, 13. "Redução Da Violência Comemorada por Moro É Vista com Cautela por Especialistas." Retrieved April 17, 2020 from https://www.em.com. $\mathrm{br} / \mathrm{app} /$ noticia/politica/2019/10/13/interna_politica,1092366/reducao-da-violencia-comemorada-por-moro-e-vista-com-cautela-por-espe.shtml

Estado de Minas. 2019a, March 03. "Bolsonaro Compartilha de Vídeo Sobre Decisão do STF." Retrieved April 20, 202 from https://www.em.com.br/app/noticia/politica/2019/03/16/interna_politica,1038504/bolsonaro-compartilha-de-video-sobre-decisao-do-stf.shtml

Exame. 2019, November 13. "Briga Doria-Bolsonaro Deixa Obras Sob Impasse." Retrieved April 03, 2020 from https:/ /exame.abril.com.br/brasil/briga-doria-bolsonaro-deixaobras-sob-impasse/

Exame. 2019a, August 13. "Moro Divulga Queda da Criminalidade em 2019, Mas Dados São Incompletos." Retrieved April 17, 2020 from https://exame.abril.com.br/brasil/moro-divulga-queda-da-criminalidade-em-2019-mas-dados-sao-incompletos /

Extra. 2020, February 16. "Bolsonaro Teve 40 Compromissos Oficiais Com Evangélicos Só em 2019." Retrieved April 20, 2020 from https://extra.globo.com/noticias/brasil/bolsonaro-teve-40-compromissos-oficiais-com-evangelicos-so-em-2019-24251823.html

Folha de São Paulo. 2018, October 10. "Bastam um Soldado e um Cabo para Fechar STF, Disse Filho de Bolsonaro em Vídeo." Retrieved April 20, 2020 from https://www1.folha. uol.com.br/poder/2018/10/basta-um-soldado-e-um-cabo-para-fechar-stf-disse-filho-de-bolsonaro-em-video.shtml 
Folha de São Paulo. 2019, March 22. "Maia Diz Que Bolsonaro Deve Ter Mais Tempo para Previdência e Menos para Twitter." Retrieved 23 June, 2020 from

https://www1.folha.uol.com.br/mercado/2019/03/maia-diz-que-bolsonaro-deve-termais-tempo-para-previdencia-e-menos-para-twitter.shtml

Folha de São Paulo. 2019a, June 13. "Bolsonaro Demite General Santos Cruz, e Outro Militar Assume Secretaria de Governo." Retrieved May 10, 2020 from https://www1. folha.uol.com.br/poder/2019/06/general-santos-cruz-deixara-ministerio-do-governo-bolsonaro.shtml

Folha de São Paulo. 2019b, August 27. "Após Ofender Mulher de Macron, Bolsonaro Diz que Não a Ofendeu." Retrieved April 02, 2020 from https://www1.folha.uol.com. $\mathrm{br} / \mathrm{mundo} / 2019 / 08 /$ apos-ofender-mulher-de-macron-bolsonaro-diz-que-nao-aofendeu.shtml

Folha de São Paulo. 2019c, November 20. "Bolsonaro Amplia Ameaça à Folha e Diz Que Boicota Produtos de Anunciantes do Jornal." Retrieved March 20, 2020 from https:/ / www1.folha.uol.com.br/poder/2019/11/bolsonaro-amplia-ameaca-a-folha-e-dizque-boicota-produtos-de-anunciantes-do-jornal.shtml

Folha de São Paulo. 2019d, December 20. “Bolsonaro Ataca Repórter Após Perguntas Sobre Flávio e Queiroz: 'Você Tem uma Cara de Homossexual Terrível'." Retrieved April 10, 2020 from https:/ / www1.folha.uol.com.br/poder/2019/12/bolsonaro-ataca-reporter-apos-pergunta-sobre-queiroz-voce-tem-uma-cara-de-homossexual-terrivel.shtml

Folha de São Paulo. 2020, January 16. "Bolsonaro Foi Autor de 58\% dos Ataques Contra Jornalistas em 2019, Diz Entidade." Retrieved April 10, 2020 from https:/ /www1.folha. uol.com.br/poder/2020/01/bolsonaro-foi-autor-de-58-dos-ataques-contra-jornalistas-em-2019-diz-entidade.shtml

Folha de São Paulo. 2020a, February 03. "Bolsonaro Afirma Que Transferirá Embaixada para Jerusalém até 2021." Retrieved June 23, 2020 from https://www1.folha.uol. com.br/mundo/2020/02/bolsonaro-afirma-que-transferira-embaixada-para-jerusalem-ate-2021.shtml

G1. 2019, February 18. “Governo Anuncia Demissão de Bebianno; Floriano Peixoto Assume Secretaria-Geral." Retrieved April 10, 2020 from https://g1.globo.com/politica/ noticia/2019/02/18/porta-voz-anuncia-demissao-de-gustavo-bebianno-da-secretaria-geral.ghtml

G1. 2019a, April 08. "Bolsonaro Demite Vélez e Nomeia Abraham Weintraub como Ministro da Educação." Retrieved March 12, 2020 from https://g1.globo.com/politica/noticia/2019/04/08/planalto-anuncia-demissao-de-ricardo-velez-rodriguez-do-ministerio-da-educacao.ghtml

G1. 2019b, March 18. "Brasil Assina Acordo Que Permite aos EUA Lançar Satélites da Base de Alcântara." Retrieved June 23, 2020 from https://g1.globo.com/politica/noticia/2019/03/18/brasil-assina-acordo-que-permite-aos-eua-lancar-satelites-da-basede-alcantara.ghtml

G1. 2019c, November 25. "Brasil Registra Queda de 22\% nas Mortes Violentas em 9 Meses, Revela Índice Nacional De Homicídios." Retrieved April 02, 2020 from https:/ /g1.globo.com/monitor-da-violencia/noticia/2019/11/25/brasil-registra-queda-de-22percent-nas-mortes-violentas-em-9-meses-revela-indice-nacional-de-homicidios.ghtml

G1. 2019d, May 27. "Plano Nacional de Educação Está Com 80\% das Metas Estagnadas, Diz Estudo." Retrieved March 10, 2020 from https://g1.globo.com/educacao/noticia/2019/05/27/plano-nacional-de-educacao-esta-com-80percent-das-metas-estagnadas-diz-estudo.ghtml

Giambiagi, Fabio, André Arruda Villela, Lavínia B. Castro and Jennifer Hermann. 2005. Economia Brasileira Contemporânea: 1945-2004. Rio de Janeiro: Elsevier.

Giambiagi, Fabio, André Arruda Villela, Lavínia B. Castro and Jennifer Hermann. 2011. Economia Brasileira Contemporânea: 1945-2010. Rio de Janeiro: Elsevier.

Gonçalves, Williams and Tatiana Teixeira. 2020. "Considerações sobre a política externa brasileira no governo Bolsonaro e as relações EUA-Brasil." Sul Global 1(1): 192-211. 
Hochstetler, Kathryn. 2006. "Rethinking Presidentialism: Challenges and Presidential Falls in South America." Comparative Politics 38 (4): 401-418.

IBGE. 2019, April 30. "PNAD Contínua: Taxa de Desocupação É de 12,7\% e Taxa de Subutilização É de 25,0\% no Trimestre Encerrado em Março de 2019." Retrieved May 05, 2020 from https://agenciadenoticias.ibge.gov.br/agencia-sala-de-imprensa/2013-agencia-de-noticias/releases / 24284-pnad-continua-taxa-de-desocupacao-ede-12-7-e-taxa-de-subutilizacao-e-de-25-0-no-trimestre-encerrado-em-marco-de-2019

IBGE. 2020, January 10. "Em Dezembro, IPCA Foi de 1,15\% e Acumulou Alta de 4,31\% em 2019." Retrieved April 10, 2020 from https://agenciadenoticias.ibge.gov.br/agencia-sala-de-imprensa/2013-agencia-de-noticias/releases/26619-em-dezembro-ipcafoi-de-1-15-e-acumulou-alta-de-4-31-em-2019

IBGE. 2020a, March 04. "PIB Cresce 1,1\% em 2019 e Fecha o Ano em R \$ 7,3 Trilhões." Retrieved April 05, 2020 from https://agenciadenoticias.ibge.gov.br/agencia-sala-de-imprensa / 2013-agencia-de-noticias / releases / 27006-pib-cresce-1-1-em-2019-e-fecha-o-anoem-r-7-3-trilhoes

IBGE 2020b, January 31. “PNAD Contínua: Taxa de Desocupação É de 11,0\% E Taxa de Subutilização É de 23,0\% No Trimestre Encerrado em Dezembro." Retrieved April 10, 2020 from https://agenciadenoticias.ibge.gov.br/agencia-sala-de-imprensa/2013-agencia-de-noticias / releases / 26740-pnad-continua-taxa-de-desocupacao-e-de-11-0-etaxa-de-subutilizacao-e-de-23-0-no-trimestre-encerrado-em-dezembro

IBGE. 2020c, February 14. “Desemprego Cai em 16 Estados em 2019, Mas 20 Têm Informalidade Recorde." Retrieved April 10, 2020 from https://agenciadenoticias.ibge.gov. br/agencia-noticias/2012-agencia-de-noticias/noticias/26913-desemprego-cai-em16-estados-em-2019-mas-20-tem-informalidade-recorde

IBRE. 2019, May 22. "Income Inequality in Brazil Reaches Record High, FGV IBRE Survey Shows." FGV. Retrieved April 15, 2020 from https:/ / portal.fgv.br/en/news/incomeinequality-brazil-reaches-record-high-fgv-ibre-survey-shows

Jornal do Brasil. 2020, October 29. "Bolsonaro Pede Desculpas ao STF Após Declaração de Ministro por Vídeo de Leão Com Hienas." Retrieved April 20, 2020 from https:/ / www.jb.com.br/pais/2019/10/1019276-bolsonaro-pede-desculpas-ao-stf-aposdeclaracao-de-ministro-por-video-de-leao-com-hienas.html

Jornal Nacional. 2019, June 21. "Bolsonaro Anuncia Novo Ministro da Secretaria-Geral da Presidência." Retrieved April 13, 2020 from https://g1.globo.com/jornal-nacional/ noticia/2019/06/21/bolsonaro-anuncia-novo-ministro-da-secretaria-geral-da-presidencia.ghtml

Lavareda, José Antônio 1991. A Democracia nas Urnas: O Processo Partidário Eleitoral Brasileiro. Rio de Janeiro: IUPERJ.

Lima, Maria Regina S. and Marianna Albuquerque. 2019. "O Estilo Bolsonaro de Governar e a Política Externa." Boletim OPSA 1 (Jan/Mar): 15-21.

Lima Júnior, Olavo B. 1999. "Eleições Presidenciais: Centralidade, Contexto e Implicações." Revista Brasileira de Ciências Sociais 14(40): 11-30.

Mainwaring, Scott. 1999. Rethinking Party Systems in the Third Wave of Democracy: The Case of Brazil. Stanford: Stanford University Press.

Mainwaring, Scott, Timothy J. Power and Fernando Bizzarro. 2018. "The Uneven Institutionalization of a Party System: Brazil." In Party Systems in Latin America: Institutionalization, Decay, and Collapse, edited by Scott Mainwaring. New York: Cambridge University Press, 174-75.

Mainwaring, Scott and Timothy R. Scully. 1995. "Introduction: Party Systems in Latin America." In Building Democratic Institutions: Party Systems in Latin America, edited by Scott Mainwaring and Timothy R. Scully. Stanford: Stanford University Press, 1-34.

Martins Filho, João Roberto. 2003. "Forças Armadas e Política, 1945-1964: a Ante-Sala do Golpe." In O Brasil republicano, Vol. 3: O tempo da experiência democrática, edited by Jorge Ferreira and Lucilia de Almeida N. Delgado. Rio de Janeiro: Civilização Brasileira, 97-126. 
Neri, Marcelo C. 2019. “A Escalada da Desigualdade - Qual foi o Impacto da Crise sobre Distribuição de Renda e Pobreza?" Retrieved April 27, 2020 from https:/ /www.cps.fgv. $\mathrm{br} / \mathrm{cps} / \mathrm{bd} /$ docs/A-Escalada-da-Desigualdade-Marcelo-Neri-FGV-Social.pdf

Observatório Legislativo Brasileiro. 2020. “Como Votaram os Congressistas no Primeiro Ano do Governo Bolsonaro?" Núcleo de Estudos sobre o Congresso (NECON), Instituto de Estudos Sociais e Políticos (IESP), Universidade do Estado do Rio de Janeiro (UERJ). Retrieved June 23, 2020 from https://olb.org.br/como-votaram-os-congressistas-no-primeiro-ano-do-governo-bolsonaro/

O Globo. 1990, April 29. “Um Poder Que Resiste Como o 'Paraíso' Dos Privilégios.” O Globo, 11.

O Globo. 1990a, June 14. "Collor Assiste À Posse dos Novos Ministros no STF." O Globo, 3.

O Globo. 1990b, June 23. "Governo Reedita Medida Que STF Não Julga." O Globo, 6.

O Globo. 1990c, June 28. "STF derruba por 9 a 2 Redução de salários." O Globo, 6.

O Globo. 2019, March 27. "Presidência Barra Profissionais de Jornais e Rádios em Evento com Bolsonaro em SP." Retrieved April 10, 2020 from https://oglobo.globo.com/ brasil/presidencia-barra-profissionais-de-jornais-radios-em-evento-com-bolsonaro-em-sp-23555303

Oyama, Thaís. 2020. Tormenta: o Governo Bolsonaro: Crises, Intrigas e Segredos. São Paulo: Companhia das Letras.

Pérez-Liñán, Aníbal. 2014. "A Two-Level Theory of Presidential Instability." Latin American Politics and Society 56(1): 34-54.

Pion-Berlin, David and Raphael Martinez. 2017. Soldier, Politicians, and Civilians: Reforming Civil-Military Relations in Democratic Latin America. New York: Cambridge University Press.

Poder 360. 2019, January 02. "Bolsonaro Retira População LGBT de Diretrizes de Direitos Humanos." Retrieved April 10, 2020 from https://www.poder360.com.br/governo/ bolsonaro-retira-populacao-lgbt-de-diretrizes-de-direitos-humanos /

Rennó, Lucio. 2020. "The Bolsonaro Voter: Issue Positions and Vote Choice in the 2018 Brazilian Presidential Elections." Latin American Politics and Society 62 (in press).

Saraiva, Miriam. G. and Álvaro V. C. Silva. 2019. “Ideologia e pragmatismo na política externa de Jair Bolsonaro." Relações Internacionais (R:I) 64: 117-137.

Soares, Gláucio A. D. 1962. "Las Clases Sociales, los Estratos Sociales y las Elecciones Presidenciales de 1960 en Brasil." Revista Mexicana de Sociología 24(3): 895-918.

Soares, Gláucio A. D. 1973. Sociedade e Política no Brasil: Desenvolvimento, Classe e Política Durante a Segunda República. São Paulo: Difusão Europeia do Livro.

Souza, Maria do Carmo C. 1976. Estado e Partidos Políticos no Brasil (1930-1964). São Paulo: Editora Alfa-Ômega.

Valor Econômico. 2020, January 29. “Governo Central Tem Déficit Primário de R\$ 95 Bi em 2019, o Menor Desde 2014." Retrieved May 05, 2020 from https://valor.globo.com/ brasil/noticia / 2020/01/29/governo-central-tem-deficit-primario-de-r-95-bi-em2019-o-menor-desde-2014.ghtml

Valor Econômico. 2020a, February 6. "Governo de Bolsonaro dá a Primazia aos Militares." Retrieved April 14, 2020 from https://valor.globo.com/opiniao/noticia/2020/02/06/ governo-de-bolsonaro-da-a-primazia-aos-militares.ghtml

Villa, Marco A. 2016. Collor Presidente: Trinta Meses de Turbulências, Reformas, Intrigas e Corrupção. Rio de Janeiro: Record.

Weyland, Kurt. 2001. "Clarifying a Contested Concept: Populism in the Study of Latin American Politics." Comparative Politics 34(1): 1-22.

Received: April 30, 2020

Accepted: June 28, 2020 
Octavio Amorim Neto. Professor of Political Science, Brazilian School of Public and Business Administration (EBAPE), Getulio Vargas Foundation (FGV). Rio de Janeiro, Brazil. E-mail: octavio. amorim.neto@fgv.br

Gabriel Alves Pimenta. Ph.D. Candidate, Department of Political Science. University of California, Riverside, USA. E-mail: gpime002@ucr.edu 
